\title{
Treatment of postoperative pain and non-pharmacologic practices in nursing systematic review: Results of Turkish doctoral dissertation in 2000-2015
}

\author{
Postoperatif ağrı tedavisine nonfarmakolojik uygulamalar sistematik derleme: 2000-2015 \\ doktora tez sonuçları Türkiye
}

\section{Fatma AY}

\section{Summary}

Objectives: This cross-sectional descriptive study aimed to identify and summarize non-pharmacologic practices used by nurses to reduce or relieve postoperative pain and the effect of such practices on pain and to criticize current evidence.

Methods: Research data were acquired by searching in the "Turkish National Database of Dissertations" in January 02 to January 31, 2016. The research sample included 13 doctoral dissertations conducted in 2000-2015 in Turkey that meet the research criteria. The dissertations included were manually evaluated for the year of registry in the database, disciplines, sample group, type and objective of the study, methods used for pain management, methods for pain assessment, and results of the study.

Results: Of the dissertations, $84.6 \%$ were conducted in adult patient population and approximately half of them were quasiexperimental/experimental studies. When the dissertations were searched by methods of pain control, $80 \%$ of dissertations were performed on non-pharmacologic methods. Among non-pharmacologic methods, massage and relaxation exercises were the most widely used methods at $18.6 \%$.

Conclusion: Non-pharmacologic pain management is an effective way to reduce pain severity and it can be independently used by nurses. Researchers of dissertations often choose non-pharmacologic practices that have no side effects, have minimum risk, are not detrimental to patients, are easy to administer, and are cost-efficient. Effective non-pharmacologic methods specific to groups by age, sex, and medical diagnosis should be identified by literature review for each non-pharmacologic method in future studies.

Keywords: Pain management, Postoperative Pain, Nursing care, Evidence-Based Nursing, Medical Surgical Nursing.

\begin{abstract}
Özet
Amaç: Bu çalışma postoperatif ağrının azaltılması ya da giderilmesinde uygulanan hemşirelik uygulamalarını ve bu uygulamaların ağıı şiddeti üzerine etkilerini belirlemek, özetlemek, mevcut delilleri kritik etmek amacı ile kesitsel, tanımlayıcı bir araştırma olarak yapıldı.

Gereç ve Yöntem: Araştırma verileri 02-31 Ocak 2016 tarihleri arasında “Türkiye Ulusal Tez Veri Tabanı" dan yapılan araştırma ile elde edildi. Türkiye'de 2000-2015 yılları arasında yapılmış ve araştırma kriterlerine uyan 13 doktora tezi araştırmanın örneklemini oluşturdu. Araştırma kapsamına alınan tezler veri tabanına kayıt yılları, bilim dalları, örnek grubu, araştırma türü ve amacı, ağrı yönetiminde uygulanan yöntemler, ağrı değerlendirme yöntemleri ve araştırma sonuçları açısından manuel olarak değerlendirildi. Araştırma sonuçları dışındaki veriler frekans sayıları verilerek değerlendirildi.

Bulgular: Tezlerin \%53.9'u Cerrahi Hemşireliği Anabilim Dalı́nda ve \%61.5'i 2006-2010 yılları arasında yapılmıştır. Tezlerin \%84.6'sı yetişkin hasta popülasyonunda yapılmış ve yaklaşık yarısı yarı deneysel / deneysel araştırma tipindedir. Uygulanan/ araştırılan ağrı kontrol yöntemleri açısından tezler incelendiğinde \%80'inin nonfarmakolojik yöntemlerle ilgili olduğu saptandı. Nonfarmakolojik yöntemlerden masaj ve gevşeme egzersizi \%18.6 oranında en sık uygulanan yöntemlerdir.

Sonuç: Nonfarmakolojik ağı yönetimi algılanan ağrı şiddetini azaltan, hemşirelerin bağımsız olarak uygulayabileceği etkili yöntemlerdir. İncelenen tezlerde araştırmacıların genel olarak yan etkisi olmayan, hastaya zarar vermeyen, en az riske sahip, uygulanması kolay, maliyeti düşük nonfarmakolojik uygulamaları tercih ettikleri saptanmıştır. Gelecek araştırmalarda her bir nonfarmakolojik yöntemle ilgili literatür tarama araştırmalarının yapılarak, yaş, cinsiyet, tıbbi tanı gibi vb. gruplara özel etkili nonfarmakolojik yöntemlerin belirlenmesi önerilmektedir.
\end{abstract}

Anahtar sözcükler: Ağrı yönetimi, postoperatif ağrı, hemşirelik bakımı, kanıta dayalı hemşirelik, cerrahi hemşireliği.

Department of Midwifery, Faculty of Health Sicences, Istanbul Univercity, İstanbul, Turkey

Submitted: 22.12.2016 Accepted after revision: 19.01.2018 Available online date: 25.04.2918

Correspondence: Dr. Fatma Ay. Department of Midwifery, Faculty of Health Sicences, Istanbul Univercity, İstanbul, Turkey.

Phone: +90 - 212 - 4141500 e-mail: fatmaay@yahoo.com

(c) 2018 Turkish Society of Algology 


\section{Introduction}

The sensation of pain is an important defense, although it originates from a specific part of the body, stimulates the body against possible damage, and is a subjective, complicated, and unpleasant sense related to past experiences of individuals. ${ }^{[1-4]}$ Approximately $86 \%$ of patients feel pain of varying severity in the postoperative period.[5] In this period, pain is not only a stimulus that disturbs the patient but also a substantial problem that causes increased metabolism, heart rate, pulse volume, myocardial oxygen consumption, and peripheral vascular resistance as well as development of complications- such as fluidelectrolyte imbalance, hypoxia, atelectasis, pneumonia, nausea/vomiting- and many physiological disorders, such as insomnia and immobilization. ${ }^{[1,5,6]}$

Postoperative pain is induced by the intraoperative position of the patient, interventions, and tissue damage and gradually diminishes with tissue healing. ${ }^{[1,7]}$ Initially, a strong narcotic analgesic is parenterally administered within postoperative $48-72 \mathrm{~h}$ because pain is almost unavoidable and usually severe. In the late period, a weaker analgesic is orally administered. ${ }^{[2]}$

The literature underlines that team approach in particular, combination of various analgesics, and use of non-pharmacologic approaches together would be useful to reduce postoperative pain. ${ }^{[3,6,8]}$ Analgesics are essential for the management of postoperative pain, but may not always be able to adequately subside the pain. ${ }^{[3]}$ Therefore, non-pharmacologic methods used by nurses in addition to pharmacologic methods to relieve postoperative pain experienced by patients enhance the efficacy of analgesics and reduce fear and anxiety of patients. ${ }^{[3,8,9]}$ Pain management is one of the basic needs of humans and has primary priority in practices of nursing care. ${ }^{[10]}$ Several complementary and alternative medicine therapies that nurses can apply independently are used to reduce pain and anxiety. ${ }^{[6,7]}$

However, it is suggested that the effect of nonpharmacologic methods on pain is not adequately emphasized by researchers. ${ }^{[3]} \mathrm{A}$ review on nursing records reported that nurses play an active role in interventions for pain control in pain management and that pain control is the most common recorded condition for which they spend maximum time. ${ }^{[11]}$
The relevant studies have indicated that nurses do not use non-pharmacologic methods, but mostly deliver analgesics to relieve pain. ${ }^{[3,11]}$ In fact, effective outcomes can be achieved with a combination of multiple methods in pain management. In pain management, important evidence will be acquired when switching from dependent roles to independent roles with spreading of non-pharmacologic methods within nursing practices.

Nursing practices progress in practices based on results of research and "evidence-based decision making process." Strong evidence on postoperative pain management acquired by systematic reviews can be used to change current practices, improve the effectiveness of clinical care, provide more quality and reliable care, develop guidelines for care, and reduce the use and cost of analgesics.

Objective: This cross-sectional descriptive study aimed to identify and summarize non-pharmacologic practices used by nurses to reduce or relieve postoperative pain, the effect of such practices on pain, and variables affecting their effectiveness and to criticize current evidence.

\section{Questions of the study:}

- Are non-pharmacologic practices performed by nurses effective in pain management?

- Do non-pharmacologic methods used by nurses reduce the severity of postoperative pain according to results of doctoral dissertations conducted in Turkey between 2000 and 2015?

- Do dependent/independent variables affect nonpharmacologic methods used for pain management?

\section{Material and Methods}

\section{Study design}

This review was conducted following the PRISMA (preferred reporting items for systematic reviews and meta-analyses) guidelines for systematic reviews. This is a descriptive cross-sectional study. The search was made for doctoral dissertations conducted between 2000 and 2015 using the keyword "Nursing" in "Turkish National Database of Dissertations" logged in with the user password of the Higher Education Institution, Republic of Turkey. Data for this study were collected from January to February 2016. 


\section{Reasons for conducting this study with doctoral dissertations (gray literature)}

Some doctoral dissertations conducted in Turkey are published as short articles or as excerpts. However, there are also many unpublished postgraduate dissertations. In addition, a journal editor may be more willing to publish studies reporting positive results rather than those reporting negative results, which increases the possibility of publishing research articles reporting positive findings. This leads researchers to be more eager and determined and to act more quickly to publish their studies with positive findings. One reason why positive findings are published more than negative findings is that authors tend to report positive results from their studies and omit negative results (selective reporting of outcomes). The literature mostly includes articles with positive findings, and this causes the article to be referenced more and easily accessible, to be considered that outcomes are actually more effective and that such effect appears in more exaggerative manner in meta-analysis studies that combine date of studies. [12] Furthermore, doctoral dissertations are usually excluded from the evaluation of academic progress, which is the case for Turkey. Researchers are not very willing to publish the results of their doctoral dissertations. For these reasons, it is important to assess the results of studies that are completed but not published, and not only published studies. Based on this, we conducted the present study on the results of doctoral dissertations including interventions performed for the treatment of postoperative pain.

\section{Setting and sample}

The search returned a total of 3328 (2680 postgraduate and 648 doctoral) dissertations in nursing between the same years. Repeated searches were made in the database using two different combinations of keywords "Nursing," "Surgery," and "Postoperative Pain," which returned 136 dissertations that comprised the universe of research. Thus, 3192 dissertations were excluded. One hundred and three postgraduate dissertations were excluded. Of the 33 doctoral dissertations, 8 were excluded because of restriction of access to full text. Twenty-five dissertations were reassessed with manual search for the exclusion criteria of the study, and 12 dissertations were then excluded. In this universe, the study sample included 13 doctoral dissertations that were accessible and complied with the research subject and met the research criteria (Fig. 1).

\section{Ethical considerations}

The "Turkish National Database of Dissertations" was searched using the writer's user password of the Higher Education Institution, Republic of Turkey. Dissertations that were made accessible by the author were only included in the study.

\section{Measurements}

The dissertations examined with the evaluation form developed by the researchers.

\section{Data collection}

The sample was achieved using the inclusion and exclusion criteria in the universe.

\begin{tabular}{|l|}
\hline Dissertations were searched in \\
the database of Turkish Higher \\
Education Institution. $(\mathrm{n}=3328)$
\end{tabular}

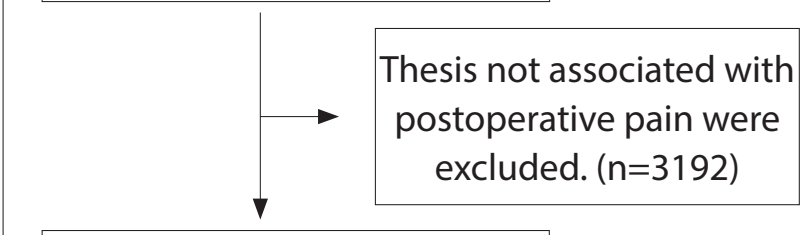

Theses were identified for detailed evaluation. $(n=136)$

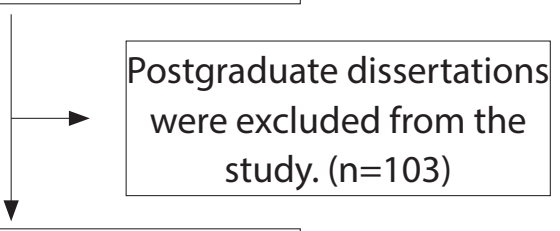

Doctoral dissertations were searched. $(n=33)$

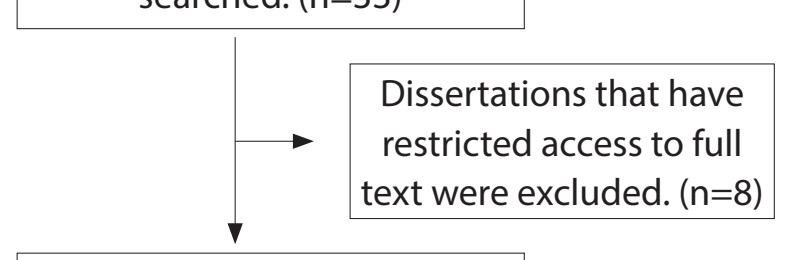

Dissertations selected were manually assessed. $(n=25)$

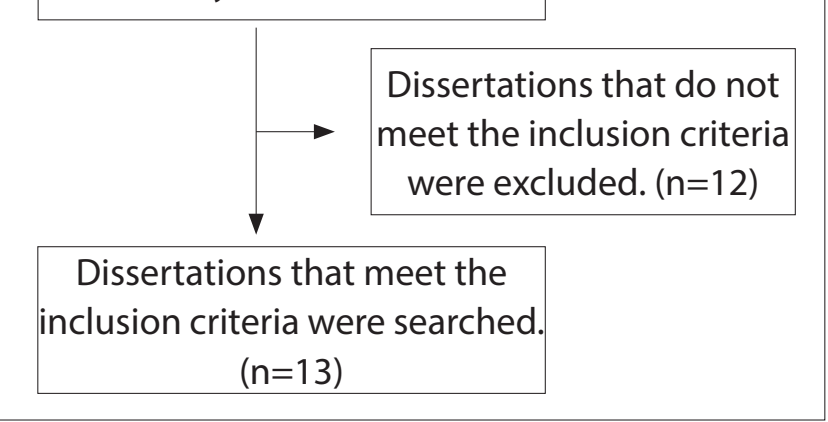

Figure 1. Flow chart of study retrieval and selection. 


\section{Inclusion criteria:}

- Dissertations on postoperative pain in surgical nursing

- Dissertations on cesarean delivery

- Dissertations with online access permitted by the researcher

- Exclusion criteria:

- Dissertations on emergency service-trauma and burn pain

- Dissertations on pain caused by diagnostic procedures (endoscopy, biopsy, mammography, examination for retinopathy, bloodletting etc.)

- Dissertations on pain caused by cancer and treatment of cancer

- Dissertations on pain caused by treatments (IM/IV/ SC injections, vaccines, dialysis, angiography etc.)

- Dissertations on labor pain, postpartum pain, perianal pain of vaginal delivery, and pain from episiotomy

- Dissertations on other pains (lumbar pain, migraine, arthralgia, acute/chronic pain etc.)

- Dissertations on job satisfaction, burnout, violence, informed consent, mobbing etc. on surgical nurses

- Dissertations on infections following surgical procedures, anxiety, self-efficacy, satisfaction with service offered, social support, quality of life, terminal care etc.

- Dissertations on matters regarding families of patients undergoing surgery

- Dissertations on operating room team and environment

- Dissertations performed with nursing students

- Problems other than pain that may occur in the postoperative period (nausea/vomiting, problems of digestive system, perception of body image etc.)

- Validation/reliability of pain scales

\section{Data analysis}

The "Turkish National Database of Dissertation" was searched for this review between January 02 and February 01, 2016. Thirteen dissertations included in the study were manually evaluated for the year of registry in the database, disciplines, sample group, type and objective of the study, methods used for pain management, methods for pain assessment, and results of the study. Data other than study results were evaluated assigning frequency numbers.

\section{Results}

All dissertations included in the present study were performed by the Department of Nursing, Graduate School of Health Sciences of relevant universities. Of these, 53.9\% were conducted for the Department of Surgical Nursing and $61.5 \%$ were conducted between 2006 and 2010; 84.6\% were conducted in adult patient population and approximately half of them were quasi-experimental/experimental studies. When searching dissertations by used/searched methods for pain control, $80 \%$ were performed on non-pharmacologic methods. Among non-pharmacologic methods, massage and relaxation exercises were the most commonly used methods at $18.6 \%$. More than half of the studies used Visual Analog Scale to assess the presence and severity of pain (Table 1).

Seven of the dissertations in Table 2 were not published. The results of published dissertations $(n=6)$ were positive, and the effect of the non-pharmacologic method used on the severity and sense of pain was positive. Of the unpublished dissertations, one investigated the effect of patient education on pain and achieved significant results; one was performed on children and found no significant relationship; two delivered training to nurses on analgesics and reported that pain severity was reduced after training. Although all the studies did not obtain statistically significant results, they all reported that non-pharmacologic methods used reduced the severity and sense of pain.

\section{Discussion}

Approximately $50 \%$ of the doctoral dissertations $(n=6)$ included in the present study were published. Other dissertations that detected non-pharmacologic methods are effective in pain management were not published as articles. This may be because articles or studies produced from doctoral dissertations are not included in the criteria for academic promotion in Turkey.

Pain severity is at the highest level in the first hours following surgery. The initial and most effective method for pain control is to deliver analgesics in the early postoperative period. Initially, a strong narcotic analgesic is parenterally administered within the postoperative $48 \mathrm{~h}$ because the pain is almost unavoidable and usually severe. This is also what is chosen by nurses. Therefore, non-pharmacologic 
Table 1. General information about the thesis subject and content $(n=13)$

\begin{tabular}{|c|c|c|}
\hline & $\mathbf{n}$ & $\%$ \\
\hline \multicolumn{3}{|l|}{ Years } \\
\hline $2000-2005$ & 1 & 7.7 \\
\hline 2006-2010 & 8 & 61.5 \\
\hline 2011-2015 & 4 & 30.8 \\
\hline \multicolumn{3}{|l|}{ Departments of nursing } \\
\hline Department of surgical nursing & 7 & 53.9 \\
\hline Department of fundamentals of nursing & 3 & 23 \\
\hline Department of children health and disease of nursing & 1 & 7.7 \\
\hline Nursing department & 2 & 15.4 \\
\hline \multicolumn{3}{|l|}{ Sample group } \\
\hline Adult patient & 11 & 84.6 \\
\hline Child patient & 1 & 7.7 \\
\hline Nurse & 1 & 7.7 \\
\hline \multicolumn{3}{|l|}{ Type of research } \\
\hline Descriptive & 2 & 15.4 \\
\hline Semi -experimental/experimental & 7 & 53.9 \\
\hline Randomized, Single-Blind, double-controlled, experimental & 4 & 30.8 \\
\hline \multicolumn{3}{|c|}{ Objective of research (Dissertations specify objective for multiple areas, $n=15$ ) } \\
\hline Research for effectiveness of education & 3 & 20 \\
\hline Research for effectiveness of pharmacologic method & 2 & 13.3 \\
\hline Research for effectiveness of education on pharmacologic method & 2 & 13.3 \\
\hline Research for effectiveness of non-pharmacologic method & 8 & 53.4 \\
\hline \multicolumn{3}{|c|}{ Used/Investigated pain control methods (Dissertations used multiple methods, $n=20$ )* } \\
\hline Pharmacologic methods & 4 & 20 \\
\hline Non-pharmacologic methods (Total)* & 16 & 80 \\
\hline \multicolumn{3}{|l|}{ Total $n=16$} \\
\hline Massage $^{*}$ & 3 & 18.6 \\
\hline Relaxation exercises* & 3 & 18.6 \\
\hline Playing therapeutic games* & 1 & 6.3 \\
\hline Hot application* & 1 & 6.3 \\
\hline Distraction* & 1 & 6.3 \\
\hline Speaking about pain with patients* & 1 & 6.3 \\
\hline Positioning/Assist in moving* & 2 & 12.5 \\
\hline Listening to music* & 1 & 6.3 \\
\hline Cold application* & 2 & 12.5 \\
\hline Exerting pressure* & 1 & 6.3 \\
\hline \multicolumn{3}{|c|}{$\begin{array}{l}\text { Means used by nurses to identify the presence and severity of pain (they used more } \\
\text { than one methods, } n=17 \text { ) }\end{array}$} \\
\hline Visual analog scale * & 9 & 52.9 \\
\hline Short McGill Melzack pain scale* & 5 & 29.4 \\
\hline Behavioral pain scale* & 1 & 5.9 \\
\hline Assessment of facial expressions scale* & 2 & 11.8 \\
\hline
\end{tabular}

* Frequency was distributed by calculating total $\mathrm{n}$ because there were more than one response.

methods used independently by nurses are more efficacious in pain management after the first 24 h. ${ }^{[1,11]}$ Two dissertations indicated that only analgesics were used for postoperative pain control, and most of the patients preferred painkillers. The other dissertations reviewed reported that a large num- ber of nurses used pharmacologic methods for the management of postoperative pain. This may be explained both by the obligation of nurses to fulfill a physician's order as required by law and favorable outcomes achieved by analgesics in postoperative acute pain. 
Table 2. Summary of Included Studies in this Systematic Review $(n=13)$

\begin{tabular}{|c|c|c|c|c|}
\hline $\begin{array}{l}\text { Author, year, } \\
\text { record no. } \\
\text { of thesis }\end{array}$ & $\begin{array}{l}\text { Participations/ } \\
\text { sample size }\end{array}$ & Study design & $\begin{array}{l}\text { Measurement } \\
\text { tools }\end{array}$ & Main results \\
\hline $\begin{array}{l}\text { A. Yava*, } \\
(2004)\end{array}$ & $\begin{array}{l}\text {-481 patients } \\
\text {-Experimental group } 247 \\
\text {-Control group } 234 \\
-44 \text { nurses }\end{array}$ & $\begin{array}{l}\text { Type of intervention } \\
\text { with the } \\
\text { experimental and } \\
\text { control groups }\end{array}$ & $\begin{array}{l}\text {-Patient definition form } \\
\text {-Questionnaire on } \\
\text { postoperative pain and } \\
\text { treatment knowledge } \\
\text {-Postoperative pain } \\
\text { observation and } \\
\text { evaluation forms } \\
\text {-Patient satisfaction } \\
\text { evaluation forms } \\
\text { - VAS }\end{array}$ & $\begin{array}{l}\text { Non-pharmacologic } \\
\text { practices performed by } \\
\text { trained nurses for } \\
\text { postoperative pain were } \\
\text { effective in reducing pain. } \\
\text { Most patients in the } \\
\text { experimental group } \\
\text { expressed this effect } \\
\text { "perfect."The results } \\
\text { showed that the number } \\
\text { of applications on the ex } \\
\text { perimental group was } \\
\text { about twice as much as } \\
\text { that of the control group } \\
\text { and more types of nur } \\
\text { sing interventions were } \\
\text { observed. Initial pain } \\
\text { score means taken just } \\
\text { after the surgery were fo } \\
\text { und to be close to each } \\
\text { other. After 3-day nursing } \\
\text { applications, the mean } \\
\text { pain scores of the } \\
\text { experimental group } \\
\text { were smaller than those } \\
\text { of the control group. }\end{array}$ \\
\hline $\begin{array}{l}\text { Y. Sayın*, } \\
(2008)\end{array}$ & $\begin{array}{l}\text { - Control group } 42 \\
\text { patients } \\
\text { - Experimental group } \\
42 \text { patients }\end{array}$ & $\begin{array}{l}\text { Semi-experimental } \\
\text { study }\end{array}$ & $\begin{array}{l}\text { - Patient definition form } \\
\text { - VAS } \\
\text { - MASF-SF }\end{array}$ & $\begin{array}{l}\text { Used only analgesics for } \\
\text { postoperative pain control, } \\
\text { and patients also choose } \\
\text { to take analgesics. The type } \\
\text { of surgical intervention af } \\
\text { fected the severity and } \\
\text { quality of pain. The } \\
\text { experimental group had } \\
\text { positive expectation for the } \\
\text { drug through "education fo } \\
\text { cused on efficacy of analge } \\
\text { sic," and this expectation re } \\
\text { duced the severity of posto } \\
\text { perative pain in patients. In } \\
\text { forming patients of the effi- } \\
\text { cacy of analgesics allowed } \\
\text { them to have more benefits } \\
\text { from the analgesics in the } \\
\text { postoperative period and } \\
\text { helped early mobilization. }\end{array}$ \\
\hline $\begin{array}{l}\text { Y. Demir, } \\
(2008)\end{array}$ & $\begin{array}{l}\text { - Application group of } 30 \\
\text { patients } \\
\text { - Interference control } \\
\text { group of } 30 \text { patients } \\
\text { - Noninterference control } \\
\text { group of } 30 \text { patients }\end{array}$ & $\begin{array}{l}\text { Randomized, double- } \\
\text { controlled study }\end{array}$ & $\begin{array}{l}\text { - Patient } \\
\text { information and approval } \\
\text { form, } \\
\text { - VAS } \\
\text { - MASF-SF } \\
\text { - The Spielbergel } \\
\text { Situational Anxiety } \\
\text { Inventory } \\
\text { Level (STAI-I) }\end{array}$ & $\begin{array}{l}\text { Found that cold application } \\
\text { reduced sensation of pain } \\
\text { felt by patients during the } \\
\text { procedure and prolonged the } \\
\text { time from removal of chest } \\
\text { tube to re-administration of } \\
\text { analgesics. A 20-min cold } \\
\text { application combined with } \\
\text { standard analgesic reduced }\end{array}$ \\
\hline
\end{tabular}


Table 2. (Cont.)

\begin{tabular}{|c|c|c|c|c|}
\hline & & & $\begin{array}{l}\text { - Pain and Anxiety } \\
\text { Following Form }\end{array}$ & $\begin{array}{l}\text { the pain experienced during } \\
\text { removal of chest tube; } \\
\text { patient's age, sex, and number } \\
\text { of chest tubes inserted did } \\
\text { not affect pain severity ex } \\
\text { perienced during the remo- } \\
\text { val of chest tube; cold } \\
\text { application did not affect } \\
\text { the number of analgesics } \\
\text { needed by patients after the } \\
\text { removal of the chest tube, } \\
\text { but affected the time to re } \\
\text { ceive the analgesics, thus } \\
\text { extended the time without } \\
\text { medication. Around } 61.1 \% \\
\text { of patients reported that } \\
\text { they used analgesics to } \\
\text { cope with the pain in their } \\
\text { daily life. }\end{array}$ \\
\hline $\begin{array}{l}\text { B. Ucuzal, } \\
\text { (2009) }\end{array}$ & $\begin{array}{l}\text {-Control group } 35 \text { patients } \\
\text { - Experimental group } 35 \\
\text { patients }\end{array}$ & $\begin{array}{l}\text { Semi-experimental } \\
\text { study }\end{array}$ & $\begin{array}{l}\text { - Questionnaire Form } \\
\text { - MASF-SF }\end{array}$ & $\begin{array}{l}\text { The data obtained showed } \\
\text { that foot massage applied } \\
\text { on patients undergoing } \\
\text { mastectomy was effective in } \\
\text { postoperative pain control. } \\
\text { Patients in the experimental } \\
\text { group statistically signifi } \\
\text { cantly felt less pain. }\end{array}$ \\
\hline $\begin{array}{l}\text { F. E. } \\
\text { Büyükyılmaz } \\
\text { (2009) }\end{array}$ & $\begin{array}{l}\text {-Control group } 30 \text { patients } \\
\text {-Experimental group } 30 \\
\text { patients }\end{array}$ & -Experimental study & $\begin{array}{l}\text { - Patient definition form } \\
\text { - VAS } \\
\text { - MASF-SF }\end{array}$ & $\begin{array}{l}\text { Relaxation exercises } \\
\text { performed by patients } \\
\text { undergoing total hip/total } \\
\text { knee arthroplasty and } \\
\text { massage on dorsum were } \\
\text { effective in reducing the } \\
\text { severity of postoperative } \\
\text { pain and level of anxiety. } \\
\text { There were no significant } \\
\text { differences between } \\
\text { experimental and control } \\
\text { groups in terms of age, sex, } \\
\text { and past experience. }\end{array}$ \\
\hline $\begin{array}{l}\text { N. Ertuğ, } \\
\text { (2009) }\end{array}$ & $\begin{array}{l}\text { - Control group } 70 \text { patients } \\
\text { - Experimental group } 70 \\
\text { patients }\end{array}$ & - Experimental study & $\begin{array}{l}\text { - Patient definition form } \\
\text {-VAS }\end{array}$ & $\begin{array}{l}\text { Cold application was } \\
\text { effective to reduce pain } \\
\text { induced by the removal of } \\
\text { chest tubes. Age, sex, and } \\
\text { number of days in which the } \\
\text { chest tube stayed in the } \\
\text { body did not affect pain } \\
\text { developed after the removal } \\
\text { of chest tube. More than } \\
90 \% \text { of patients reported } \\
\text { that they used analgesics to } \\
\text { cope with the pain. More } \\
\text { than } 50 \% \text { of patients } \\
\text { indicated that the severity of } \\
\text { pain was increased by } \\
\text { moving, breathing, coughing, } \\
\text { and moving chest tube, and } \\
\text { reduced by analgesics and } \\
\text { immobility. }\end{array}$ \\
\hline
\end{tabular}


Table 2. (Cont.)

$\begin{array}{llll}\text { E. Kol*, } & \text {-Control group 35 patients } & \text { - Prospective, } & \text { - Patient information and } \\ (2010) & \text { - Experimental group 35 } & \text { randomized } & \text { approval form } \\ & \text { patients } & \text { controlled and single- } & \text { - Verbal Category Scale } \\ & \text { blinded experimental } & \text { - Behavioral Pain } \\ & \text { study } & \text { Scale } \\ & & - \text { VAS }\end{array}$

Quantity of analgesics needed by patients of the study group was lower than that of the control group, and this was statistically significant. As a result, the "Care Protocol" used for pain control following thoracotomy was effective in pain control.

$\begin{array}{ll}\text { S. Faydalı*, } & -35 \text { nurses } \\ \text { (2010) } & -210 \text { patients }\end{array}$

S. K. Şahin*, $\quad-230$ patients (2010)

Y. Ciğerci, - Control group 34 patients (2012) - Experiment group 34 patients
-Interventions research

- Prospective research

-Randomized controlled clinical trials
- Questionnaire form for evaluating nurses' knowledge and their practice

- Patient follow-up form - Modified Aldrete Scoring System -VAS

Training on principles for the quality use of analgesics improved knowledge and practices of nurses and had positive effects.

$95.8 \%$ of patients aged $\geq 72$, $77.6 \%$ of female patients, $81.1 \%$ with tube/drain, and $74.8 \%$ with surgical experience had pain that required intervention. The age, therapy of analgesics, and care approach in the Postanesthesia Care Unit were the most important factors for development of moderate and severe pain.

- Patient information and approval form - VAS

- The Spielbergel Situational Anxiety Inventory Level (STAI-I and II)
T. Sağkal Midilli, (2012)

\footnotetext{
- Control group 45 patients - Experimental group 45 patients
}

$\begin{array}{ll}\text { - Randomized } & \text { - Patient description form } \\ \text { controlled clinical trials } & \text { - VAS } \\ & \text { - State Anxiety Inventory } \\ & \text { - Patient follow-up form } \\ & \text { - Psychodynamic respond } \\ & \text { list experienced in Reiki } \\ & \text { practice } \\ & \text { - Questionnaire on the }\end{array}$

There were no differences between the postoperative consumption of analgesics and severity of pain felt by patients who underwent coronary artery bypass graft (CABG) and listened to music and the postoperative con sumption of analgesics and the severity of pain felt by CABG patients who did not listen to music.

The severity of pain and number of analgesics used by patients of experimental group were significantly low in the intensive care and surgical service.

Reiki reduced the mean score of pain experienced by patients undergoing cesarean section. The severity of pain was reduced by $66.75 \%$ between the measurement I and IV in patients of the application Implementation of Reiki group. The time to taking next analgesics after appli cation was the longest at 
Table 2. (Cont.)

\begin{tabular}{|c|c|c|c|c|}
\hline $\begin{array}{l}\text { E. Tural*, } \\
(2012)\end{array}$ & $\begin{array}{l}\text { - Control group } 100 \\
\text { patients } \\
\text { - Education group } 100 \\
\text { patients } \\
\text { - Education + play group } \\
100 \text { patients }\end{array}$ & $\begin{array}{l}\text { - Sectional, } \\
\text { - Semi-experimental } \\
\text { study }\end{array}$ & $\begin{array}{l}\text { - State-Trait Anxiety } \\
\text { Inventory for Children } \\
\text { (STAl-for children), } \\
\text { - The Scale of Fear of } \\
\text { Medical Procedures and } \\
\text { Wong } \\
\text { - Baker's "The Faces Pain } \\
\text { Rating Scale" } \\
\text { - The question form }\end{array}$ & $\begin{array}{l}\text { Children's sociodemographic } \\
\text { characteristics, previous } \\
\text { experience in hospitals and } \\
\text { surgeries did not affect the } \\
\text { level of preoperative and } \\
\text { postoperative pain. } \\
\text { Preparation of children for } \\
\text { surgery using therapeutic } \\
\text { games in the preoperative } \\
\text { period did not have any } \\
\text { effect on the level of pain in } \\
\text { the postoperative period. }\end{array}$ \\
\hline $\begin{array}{l}\text { N. Taşdemir*, } \\
\text { (2012) }\end{array}$ & $\begin{array}{l}\text { - Control group } 25 \\
\text { patients } \\
\text { - Experimental group } \\
25 \text { patients }\end{array}$ & - Experimental study & $\begin{array}{l}\text { - Patient information and } \\
\text { approval form } \\
\text { - VAS } \\
\text { - Patient satisfaction } \\
\text { evaluation forms }\end{array}$ & $\begin{array}{l}\text { The level of pain increased } \\
\text { with increased height, } \\
\text { weight, duration of surgery, } \\
\text { and duration of anesthesia. } \\
\text { The need of analgesics of } \\
\text { patients in the intervention } \\
\text { group was lower. Study } \\
\text { results indicated that } \\
\text { relaxation, aromatherapy, } \\
\text { and a combination of both } \\
\text { used complementary to tre } \\
\text { atment for reducing posto } \\
\text { perative pain reduced the } \\
\text { requirement of analgesics. } \\
\text { The score of pain sensed by } \\
\text { smoker patients and } \\
\text { measured at } 15 \text { and } 30 \text { min } \\
\text { was higher than that of } \\
\text { non-smoker patients. }\end{array}$ \\
\hline
\end{tabular}

days 1 and 2 for patients of the application group com pared with the patients of the control group.

As a result, Reiki, a touch therapy, applied after cesarean section reduced the pain and the number of analgesics needed and ex tended the time needed for analgesics.

Children's sociodemographic characteristics, previous level of preoperati postoperative pain.

Preparation of children for effect on the level of pain in with increased height, urgery The need of analgesics of results indicated that atment for reducing posto perative pain reduced the turics. smoker patients and was higher than that of

\footnotetext{
* It is not specified in the list of references as it is an unpublished research;VAS: Visual Analog Scale, MASF-SF: Short Form McGill Pain Questionnaire.
}

The severity of pain is difficult to assess. In pain, which is a subjective sense, patients give different responses to a painful stimulant. It is important to have a full pain assessment for the effective treatment of pain. ${ }^{[11]}$ It is important to assess by nurses the patient's pain periodically before and after the surgery, whenever new pain is reported, before and after therapy, and whenever dose or treatment is changed. The assessment will guide to determine the optimum dose of analgesics and frequency of administration. ${ }^{[1]}$ For measurement of pain, one-dimensional methods (numerical criterion), multidimensional methods (McGill Pain Questionnaire, Short Pain Questionnaire) may be used. ${ }^{[9]}$ The literature reports that most nurses do not use any scales to assess the severity of postoperative pain, and the most substantial obstacle to effective pain management is failure to collect and assess data systematically. ${ }^{[3,11]}$ All dissertations included in the present study used different scales or questionnaires for assessing pain. This is consis- 
tent with the information that pain is a subjective sense and each individual feels pain at different levels. Therefore, making pain, a subjective condition, an objective condition will help treatment planning and maintaining the effectiveness of the treatment. Also, it is important to collect data using a measurable tool because most studies performed under dissertations are experimental.

The most important factors causing drug errors are caretakers' insufficient knowledge and failure to put their knowledge into practice. ${ }^{[13]}$ Leape et al. ${ }^{[1]}$ performed a study with nurses, physicians, and pharmacists to identify the underlying causes for drug errors and found that $29 \%$ of 334 errors, which occurred in 6 months, were due to insufficient knowledge of drugs. The literature has research results that reveal nurses' insufficient knowledge on analgesics. ${ }^{[1,14]}$ According to one of the dissertation results, training delivered on principles for the quality use of analgesics had a positive influence on nurses' knowledge and practices. Another research reported that informing patients on the efficacy of analgesics used by them allowed them to have more benefits from the efficacy of analgesics in the postoperative period and helped early mobilization. Furthermore, there is a linear relationship between anxiety and perception of anxiety and perception of pain severity. Thus, education and information provided in the preoperative period reduces the perception of pain severity. ${ }^{[11]}$ This minimizes the need for analgesics.

The use of non-pharmacologic methods alone and combination with pharmacologic methods reduce pain severity. ${ }^{[2]}$ Among non-pharmacologic methods used in the postoperative period, the widely used ones include massage, distraction, listening to music, cold application, relaxation exercises, and positive imagining/psychological support. ${ }^{[3,11,15]}$ On the other hand, Akupunktur, Reiki is now widely used to relieve pain, especially postoperative pain, and to facilitate patient recovery. ${ }^{[6]}$ The most frequently used non-pharmacologic methods by reviewed dissertations for pain control were massage and relaxation exercises. This indicates that non-pharmacologic methods are mostly chosen by dissertation research, which are easy to use and teach and are cost-efficient and have immediate effect.

Studies on massage, one of the peripheral techniques, found that massaging relieved or reduced pain, increased the release of endorphin, thus enhancing pain threshold, and reduced the perception of pain. ${ }^{[2,3,11,16]}$ Wang and Keck reported that patients have mild pain even when they receive analgesics postoperatively, and massaging had effect of the mild pain experienced after analgesics. ${ }^{[3]}$ According to the three dissertations results on the effect of massage on pain, massage therapy is effective for postoperative pain control. Similar to massage, Reiki is a touch therapy. Reiki is said to enhance physical and psychological comfort and well-being and enable relaxation. Recent studies have suggested that Reiki has very positive effects on reducing stress and on management of acute pain and is an effective method for pain management. ${ }^{[17]}$ Reiki is noninvasive, has no known side effects, has no negative effects on existing treatments or therapy, and is inexpensive. Therefore, nurses can use Reiki as part of the application of non-pharmacologic therapeutic interventions for pain management. ${ }^{[6]}$ According to one of the thesis results, Reiki application reduced pain intensity, anxiety, and breathing rate, as well as analgesic requirements postcesarean delivery.

Relaxation, distraction, music, imagining, and cognitive strategies are cognitive behavioral non-pharmacologic techniques. ${ }^{[2]}$ According to study results, music therapy is an effective non-pharmacologic

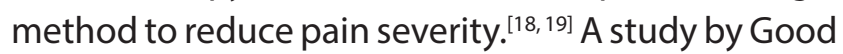
et al. suggests that relaxation and music and combination of both reduced postoperative pain. ${ }^{[20]}$ As in distraction method, music therapy allows attention to be focused on a stimulus with positive effect other than pain. ${ }^{[2,21]}$ The distraction method does not entirely eliminate patient pain, but increases the tolerance for pain and enhances the pain threshold, so the patient feels less pain. ${ }^{[2]}$ The relevant research indicates that music is effective in the management of postoperative pain. ${ }^{[2,18,21]}$ In a dissertation by $\mathrm{Ci}$ gerci, patients of the experimental group, who were made listen to music in the intensive care and surgical service, had significantly low pain severity and analgesic use.

Cold application, a non-pharmacologic method, is an effective, simple, and cheap method for pain control. ${ }^{[10]}$ Local cold application is used to control inflammation process and pain and reduce edema. $[9,10,22]$ Two of the reviewed dissertations investigated 
the association of cold application with pain and achieved favorable outcomes.

Movements such as sitting, standing, and walking are factors that induce pain and increase pain severity, especially following an abdominal surgery. However, applications such as using a corset supporting the surgical site after the abdominal surgery reduce pain severity, particularly during and after mobilization. A study by Yılmaz and Gurler ${ }^{[3]}$ indicated that $96.4 \%$ of patients experience pain when coughing, and $81.9 \%$ experience pain when getting out of bed, and they had difficulty in coughing (96.4\%), moving (78.3\%), and breathing (46.7\%) because of pain. According to the dissertation by Ertug, $>50 \%$ of patients reported that pain severity increased on moving, breathing, coughing, and moving chest tube and severity decreased by analgesics and immobility. Non-pharmacologic methods used by nurses in addition to pharmacologic methods to relieve postoperative pain experienced by patients enhance the effectiveness of pharmacologic methods. ${ }^{[3]}$ Nurses have responsibilities to teach patients breathing and coughing exercises to reduce problems that they have due to postoperative pain, assist mobilization, teach wound-supporting applications, and comfort patients giving them an appropriate position in bed. Pain sensation is a subjective, complicated, and unpleasant sense related to past experiences of individuals. Pain threshold may be affected by individual's past experiences, sociocultural level, and sex. ${ }^{[1-4,}$ ${ }^{23}$ The effect of sex on determining pain severity may be explained by hormonal differences; lower pain threshold in women; the link between metabolic enzyme systems, which differentiate in pain mechanisms and response to treatment, and sex; composition of body (higher fat rate in women); and women being more inclined to report pain and call help for their health. ${ }^{[24,25]} \mathrm{A}$ study performed by Dawson and List $^{[4]}$ found no differences between cultures, but significant differences between sexes in measurements using Painmatcher and electrical stimulus. In their systematic review, Hampton, Cavalier \& Langford ${ }^{[26]}$ suggested that results of research on relationship between sex and pain were complicated, and not only sex of patients but also sex of group of caretakers affected the sense of pain and practices. The same research found that sex affected physician's decisions but not nurse's decisions in practices for pain management. ${ }^{[26]}$ The research by Güldoğuş et al. ${ }^{[4]}$ indicated that there were no differences between sexes; however, there were significant differences in threshold values between female healthcare staff and male cleaning staff; this difference was due to occupational differences although it appeared to be differences between sexes. The results of dissertations, on the effectiveness of non-pharmacologic methods used for the management of postoperative pain, reported that factors such as age, sex, height, weight, duration of surgery, duration of anesthesia, smoking, and experience changed the effect of these methods on pain severity. Such results may be explained by complex physiopathologic processes of pain. However, in the dissertation that was made among children's, sociodemographic characteristics, previous experience in hospitals and surgeries did not have any effect on the levels of preoperative and postoperative pain. Based on results of this research, it can be concluded that sociodemographic characteristics affect pain severity, but sociodemographic characteristics affecting pain severity are different between adults and children.

Pediatric patients express pain with restless acts and crying. The most common indication of pain in newborns that are unable to verbally express their pain is crying and change in their facial expression. Anand investigated the stress response of premature and newborns to surgery and reported that such response may provide information on the measurement of pain. ${ }^{[27]}$ In the literature, most nurses (>90\%) consider crying and change in facial expression, which are best understood by mothers, as presence of pain in children. ${ }^{[23,28]}$ In their study, Jacop and Puntilla ${ }^{[23]}$ pointed out that among non-pharmacologic methods, $66.5 \%$ of nurses used distraction and $48.8 \%$ of them used relaxation to relieve the pain of pediatric patients. In a systematic review study related with the subject, it was mentioned that findings regarding the relevance between therapeutic game and pain perception of children are inconsistent and that the empirical evidence is inadequate. ${ }^{[29]}$ One of the dissertations identified that preparation of children for surgery using therapeutic games in the preoperative period did not have any effect on the level of pain in the postoperative period. Contrary to common belief, the author also reported that children's sociodemographic characteristics and their previous experience 
in hospitals and surgery did not have any effect on the level of preoperative and postoperative pain.

\section{Conclusion}

Non-pharmacologic pain management is an effective method that reduces the severity of pain and can be independently used by nurses. Different nonpharmacologic methods were used in the postoperative period as required by the methodology of the reviewed dissertations, but nurses usually chose analgesics for the management of postoperative pain according to research data. This is also what was chosen by patients.

Researchers of reviewed dissertations often chose non-pharmacologic practices, which have no side effects and minimal risks, are not detrimental to patients, are easy to perform, and are cost-efficient.

According to research results, sociodemographic characteristics affecting pain severity, such as age, sex, and experience, had different effects in children and adults. In addition, smoking had negative effect on pain severity.

Non-pharmacologic methods that can be independently used by nurses and together with pharmacologic methods are effective methods for pain management. Literature review should be conducted on each non-pharmacologic method to identify effective non-pharmacologic methods specific to groups such as age, sex, and medical diagnosis.

Meta-analysis should also be performed on the effectiveness of non-pharmacologic practices for nursing functions and to identify effective non-pharmacologic practices.

As a result, pain is a common complication of the postoperative period. This leads to the perception that patients experiencing pain is normal. In general, both physicians/nurses and patients choose analgesics for pain management in the postoperative period. In fact, non-pharmacologic practices for pain management improve the efficacy of drug therapy and patient comfort and are easy to apply. Furthermore, non-pharmacologic practices are very effective for pain management, which can be actively performed by nurses within the healthcare system and which allow nurses to have an active role in pain management and to prove their professional independency. Dissertations included in the research were performed on different non-pharmacologic methods. Evidence-based results are needed to generalize the use of non-pharmacologic methods for pain management among nurses. Use of these methods, which can be independently used by nurses, are cost-efficient, have little or no side effects, for pain management will result in favorable outcomes such as reduced use of analgesics, early ambulation, and increased patient satisfaction.

\section{Peer-rewiew: Externally peer-reviewed.}

\section{References}

1. Faydalı S. Quality Use of Analgesics in Surgical Patients. Hacettepe Üniversitesi Hemşirelik Fakültesi Dergisi 2010;17:83-91.

2. Özveren H. Non-Pharmacological Methods at Pain Management, Sağlık Bilimleri Fakültesi Hemşirelik Dergisi 2011;18:83-92.

3. Yılmaz M, Gürler H. Nursing approaches toward postoperative pain in patients: patients' opinions. Agri 2011;23(2):71-9.

4. Güldoğuş F, Kelsaka E, Öztürk B. The effect of gender and working conditions on pain threshold in healthy volunteers. Agri 2013;25(2):64-8. [CrossRef]

5. Erden V, Yıldız AS, Güler C, Aydın N, Hamzaoğlu N, Delatioğlu $\mathrm{H}$, et al. Postoperative analgesic effect of acupuncture in laparoscopic cholecystectomy surgery. Agri 2015;27(3):155-9.

6. Midilli TS, Eser I. Effects of Reiki on Post-cesarean Delivery Pain, Anxiety, and Hemodynamic Parameters: A Randomized, Controlled Clinical Trial. Pain Manag Nurs 2015;16(3):388-99. [CrossRef]

7. Büyükyilmaz $F E$, Aşti T. Postoperative pain characteristics in Turkish orthopedic patients. Pain Manag Nurs 2010;11(2):76-84. [CrossRef]

8. Büyükyılmaz $F$, Aştı T. The effect of relaxation techniques and back massage on pain and anxiety in Turkish total hip or knee arthroplasty patients. Pain Manag Nurs 2013;14(3):143-54. [CrossRef]

9. Arslan S, Celebioglu A. Postoperative pain management and alternative applications. Insan Bilimleri Dergisi 2004;1:1-7.

10. Demir Y, Khorshid L. The effect of cold application in combination with standard analgesic administration on pain and anxiety during chest tube removal: a single-blinded, randomized, double-controlled study. Pain Manag Nurs 2010;11(3):186-96. [CrossRef]

11. Ay F, Alpar SE. Approaches taken by nurses in treating postoperative pain. Agri 2010;22(1):21-9.

12. Ata B, Urman B. Critical appraisal of systematic reviews. Turk J Obstet Gynecol 2008;5:233-40.

13. Acaroğlu R, Aştı T. Hemşirelikte Sık Karşılaşılan Hatalı Uygu- 
lamalar, C.Ü.Hemşirelik Yüksekokulu Dergisi 2000;4: 22-7.

14. Demir Y, Yıldırım Usta Y, Ince Y, Türken Gel K, Kaya Akçı M. Determining of Nurses' Knowledge, Behavior and Clinical Decision Making Regarding Pain Management, Journal of Contemporary Medicine 2012;2:162-72.

15. Akbaş M, Oztunç G. Examination of knowledge about and nursing interventions for the care of patients in pain of nurses who work at Cukurova University medical faculty Balcali hospital. Pain Manag Nurs 2008;9(3):88-95. [CrossRef]

16. Ucuzal M, Kanan N. Foot massage: effectiveness on postoperative pain in breast surgery patients. Pain Manag Nurs 2014;15(2):458-65. [CrossRef]

17. Sağkal T, Eşer I, Uyar M. The Effect of Reiki Touch Therapy on Pain and Anxiety, Spatula DD 2013;3:141-6. [CrossRef]

18. Sin WM, Chow KM. Effect of Music Therapy on Postoperative Pain Management in Gynecological Patients: A Literature Review. Pain Manag Nurs 2015;16(6):978-87. [CrossRef]

19. Ciğerci Y, Özbayır T. The effects of music therapy on anxiety, pain and the amount of analgesics following coronary artery surgery. Turk Gogus Kalp Dama 2016;24:44-50.

20. Good M, Stanton-Hicks M, Grass JA, Cranston Anderson G, Choi C, Schoolmeesters LJ, et al. Relief of postoperative pain with jaw relaxation, music and their combination. Pain 1999;81(1-2):163-72. [CrossRef]

21. Özer N, Karaman Özlü Z, Arslan S, Günes N. Effect of music on postoperative pain and physiologic parameters of patients after open heart surgery. Pain Manag Nurs 2013;14(1):20-8. [CrossRef]

22. Ertuğ N, Ulker S. The effect of cold application on pain due to chest tube removal. J Clin Nurs 2012;21(5-6):784-90.

23. Göl I, Onarıcı M. Nurses' Knowledge and Practices About Pain and Pain Control in Children. Hacettepe Üniversitesi Hemşirelik Fakültesi Dergisi 2015;2:20-9.

24. Keogh E, Herdenfeldt M. Gender, coping and the perception of pain. Pain 2002;97(3):195-201. [CrossRef]

25. Sahin S. Gender and pain. Agri 2004;16(2):17-25.

26. Hampton SB, Cavalier J, Langford R. The Influence of Race and Gender on Pain Management: A Systematic Literature Review. Pain Manag Nurs 2015;16(6):968-77. [CrossRef]

27. Dinçer S, Yurtçu M, Günel E. Pain in Newborns and Nonpharmacologic Treatment Procedures. Selçuk Üniv Tıp Derg 2011;27:46-51.

28. Nimbalkar AS, Dongara AR, Phatak AG, Nimbalkar SM. Knowledge and attitudes regarding neonatal pain among nursing staff of pediatric department: an Indian experience. Pain Manag Nurs 2014;15(1):69-75. [CrossRef]

29. He HG, Zhu L, Chan SW, Klainin-Yobas P, Wang W. The effectiveness of therapeutic play intervention in reducing perioperative anxiety, negative behaviors, and postoperative pain in children undergoing elective surgery: a systematic review. Pain Manag Nurs 2015;16(3):425-39. [CrossRef] 